\title{
PENGARUH SIKAP SISWA PADA MATEMATIKA TERHADAP HASIL BELAJAR MATERI PERSAMAAN KUADRAT
}

\author{
Lestariningsih $^{1}$, Baqiyatus Sholichah ${ }^{2}$ \\ ${ }^{1,2}$ STKIP PGRI Sidoarjo \\ e-mail: ${ }^{1)}$ lestariningsih@ @ stkippgri-sidoarjo.ac.id, ${ }^{2)}$ qhiqia @gmail.com
}

\begin{abstract}
Achievement is influenced by internal and external factors, learning approach. One of the internal factor examples is attitude. Therefore, the aim of the research was to know students attitude influence on their achievement in quadratic equations of mathematic. This research used quantitative through Ex Post Facto method. The data analysis included normality test through on sample kolmogorov smirnov. The result was hyphothesis test $r \neq 0$, so Ha accepted and $\mathrm{HO}$ refused through correlation coefficient $r$ hitung $=0,907$ through $N=25$ and level eror $1 \%$ obtained $r$ tabel $=$ 0,505 can be concluded $r$ hitung $>r$ tabel, It's mean there was relationship between students attitude of students achievement in mathematic subject through strong interpretation level. Through analysis linear regression $Y \square=19,8+0,99 x$ and determination coefficient $82,3 \%$ and the result $F_{-}($hitung $)=107,221 . F_{-}($tabel $)=$ 4,28 can be concluded $F_{-}$( hitung) bigger than $F_{-}($tabel) 107,221 > 4,28 there for $\mathrm{HO}$ refused and $\mathrm{Ha}$ accepted. The achievement of mathematic influenced by $82,3 \%$ students attitude, the result was 17,7\% influenced by another factor.
\end{abstract}

Keywords : Students Attitude, Mathematics, Quadratic Equations, Achievement

\begin{abstract}
Abstrak
Hasil belajar dipengaruhi oleh faktor internal, faktor eksternal dan pendekatan belajar salah satunya pada faktor internal, contohnya sikap. Tujuan penelitian ini adalah untuk mengetahui pengaruh sikap siswa pada matematika terhadap hasil belajar siswa. Jenis penelitian ini adalah penelitian Kuantitatif dengan menggunakan metode Ex Post Facto. Dengan hasil uji hipotesis diperoleh harga $\mathrm{r} \neq 0$ maka Ha diterima dan $\mathrm{H}_{0}$ ditolak dengan koefisien korelasi $\mathrm{r}$ hitung $=0,907$ dengan $\mathrm{N}=25$ dan taraf kesalahan $1 \%$ diperoleh $\mathrm{r}$ tabel $=0,505$ dapat disimpulkan $\mathrm{r}$ hitung $>\mathrm{r}$ tabel, yang berarti ada hubungan antara sikap siswa pada matematika terhadap hasil belajar matematika dengan tingkat interpretasi sangat kuat. Dengan persamaan analisis regresi linear sederhana $\mathrm{Y} \square=19,8+0,99 \mathrm{x}$ dengan koefisien determinasi sebesar $82,3 \%$ dan hasil perhitungan F_( hitung $)=107,221$ dengan $F_{-}($tabel $)=4,28$ dapat disimpulkan F_( hitung) lebih besar dari pada F_( tabel) yaitu 107,221 > 4,28 sehingga H_0 ditolak dan H_a diterima. Hasil belajar matematika dipengaruhi sebesar $82,3 \%$ oleh sikap siswa pada matematika, sisanya $17,7 \%$ dipengaruhi oleh faktor lain.
\end{abstract}

Kata Kunci: Sikap Siswa, Matematika, Persamaan Kuadrat, Hasil Belajar 


\section{PENDAHULUAN}

Pendidikan memegang peranan penting dalam kehidupan, karena pendidikan merupakan suatu sarana untuk meningkatkan dan mengembangkan kualitas Sumber Daya Manusia (SDM). Dengan diberikan pendidikan, siswa sanggup untuk berbuat dan bertindak sebagai manusia yang berkepribadian sosial. Jadi, Pendidikan merupakan proses pembelajaran yang berupa hasil belajar.

Menurut Sudjana (2011:3) "Hasil belajar siswa pada hakikatnya adalah perubahan tingkah laku. Tingkah laku sebagai hasil belajar dalam pengertian yang luas mencakup bidang kognitif, afektif dan psikomotoris". Hasil belajar setiap individu dipengaruhi oleh belajar siswa. Menurut Syah (2003:144) "Faktor-faktor yang mempengaruhi belajar siswa yaitu faktor internal, eksternal dan pendekatan belajar". Siswa yang telah menyadari tugasnya sebagai pelajar seharusnya dapat memaksimalkan hasil belajarnya. Hasil belajar matematika siswa dapat dilihat apabila tujuan pembelajaran yang telah ditetapkan dapat dicapai oleh siswa, dan sebaliknya apabila siswa tidak dapat mencapai tujuan-tujuan dari pembelajaran dapat dipastikan hasil pembelajaran tidak tercapai.

Hasil belajar matematika siswa dipengaruhi oleh faktor internal pada aspek psikologis seperti sikap, intelegensi, bakat, minat, motivasi dan kepribadian. Faktor psikologis ini merupakan faktor yang kuat dari hasil belajar. Intelegensi memang bisa dikembangkan, tetapi untuk sikap, minat, motivasi dan kepribadian sangat dipengaruhi oleh faktor psikologi diri kita sendiri.

Menurut Yusuf (2005:171) "Sikap tidak dibawa sejak lahir, melainkan dipelajari dan dibentuk melalui pengalaman-pengalaman. Sikap dapat berubah-ubah sesuai dengan keadaan lingkungan disekitar individu yang bersangkutan pada saat-saat yang berbeda". Sebagaimana proses terbentuknya sikap siswa terhadap matematika yang memerlukan waktu cukup lama. Sikap dapat terbentuk sedikit demi sedikit dari hasil interaksi siswa dengan pelajaran matematika pada saat proses belajar mengajar berlangsung. Siswa yang kurang minat dengan mata pelajaran matematika dalam belajarpun siswa lebih banyak pasif yang berakibat pada hasil belajar siswa yang cenderung menurun. Berbeda dengan siswa yang memiliki sikap positif pada matematika akan cenderung tertarik dan berusaha mempelajari matematika. Sikap pada matematika sangat penting dimiliki siswa, terutama terhadap pelajaran matematika 
karena sikap siswa pada matematika berhubungan langsung dengan hasil belajar matematika. Berdasarkan dari masalah-masalah tersebut maka tujuan dari penelitian ini adalah untuk mengetahui pengaruh sikap siswa pada matematika terhadap hasil belajar siswa.

\section{METODE PENELITIAN}

Dalam penelitian ini peneliti menggunakan pendekatan kuantitatif dengan metode Ex Post Facto. Menurut Sugiyono (2013:8) "Pendekatan kuantitatif adalah suatu pendekatan yang digunakan untuk meneliti populasi dan sampel tertentu, pengumpulan data menggunakan instrumen penelitian, analisis data bersifat statistik dengan tujuan untuk menguji hipotesis yang telah ditetapkan”.

Menurut Sukardi (2003:165) "Penelitian Ex Post Facto merupakan penelitian di mana variabel-variabel bebas telah terjadi ketika peneliti mulai dengan pengamatan variabel terikat dalam suatu penelitian". Penelitian ini dilakukan karena penelitian berhadapan dengan situasi yang variabel bebasnya tidak bisa dimanipulasi. Variabel tersebut merupakan karakteristik yang dimiliki subjek sebelum diadakan penelitian. Pada dasarnya penelitian dengan metode ini dilakukan untuk mengetahui pengaruh antara variabel bebas dan variabel terikat. Dalam penelitian ini yang diteliti adalah pengaruh sikap siswa terhadap hasil belajar matematika. Materi yang digunakan dalam penelitian ini adalah Persamaan Kuadrat dengan sampel penelitian siswa kelas VIII-A SMP Muhammadiyah 8 Tanggulangin tahun pelajaran 2015/2016. Analisis data dan pengujian hipotesis dilakukan menggunakan uji normalitas, analisis korelasi, analisis regresi linear sederhana, dan koefisien determinasi.

\section{HASIL DAN PEMBAHASAN}

Berdasarkan penelitian yang dilakukan dapat diperoleh analisis data dan pengujian hipotesis sebagai berikut:

a. Pengujian normalitas data sikap siswa pada matematika terhadap hasil belajar, dengan menggunakan uji one sample kolmogorov smirnov melalui program SPSS ditunjukkan dalam Tabel 1. 
Tabel 1.Uji Normalitas

Tests of Normality

\begin{tabular}{|c|c|c|c|}
\hline & \multicolumn{3}{|c|}{ Kolmogorov-Smirnov $^{a}$} \\
\hline & Statistic & $\mathrm{df}$ & Sig. \\
\hline Sikap Siswa Pada Matematika & .093 & 25 & $.200^{*}$ \\
\hline Hasil Belajar & .169 & 25 & .062 \\
\hline
\end{tabular}

a. Lilliefors Significance Correction

*. This is a lower bound of the true significance.

Hasil pengujian normalitas data sikap siswa pada matematika dan pengujian normalitas hasil belajar dapat disimpulkan sebagai berikut:

1) Hasil data variabel sikap siswa pada matematika memiliki nilai signifikan 0,200.

Data dinyatakan berdistribusi normal karena nilai signifikan data sikap siswa pada matematika sebesar $0,200>0,05$.

2) Hasil data variabel hasil belajar memiliki nilai signifikan 0,062. Data dinyatakan berdistribusi normal karena nilai data hasil belajar sebesar 0,062>0,05.

Berdasarkan pengujian normalitas yang diteliti ternyata semua data berdistribusi normal. Selanjutnya akan menguji hipotesis "Terdapat pengaruh sikap siswa pada matematika terhadap hasil belajar". Dengan menggunakan teknik analisis korelasi, analisis regresi linear sederhana dan koefisien determinasi.

b. Analisis Korelasi

Menghitung persamaan umum analisis korelasi dengan menggunakan program SPSS, ditunjukkan dalam Tabel 2.

Tabel 2.Analisis Korelasi

Correlations

\begin{tabular}{|ll|r|r|}
\hline & Sikap Siswa Pada \\
Matematika & Hasil Belajar \\
\hline Sikap Siswa Pada & Pearson Correlation & 1 & $.907^{\text {*** }}$ \\
Matematika & Sig. (2-tailed) & 25 & .000 \\
& $\mathrm{~N}$ & $.907^{* * *}$ & 25 \\
\hline Hasil Belajar & Pearson Correlation & .000 & 1 \\
& Sig. (2-tailed) & 25 & 25 \\
\hline
\end{tabular}

**. Correlation is significant at the 0.01 level (2-tailed). 
Setelah diperoleh $r_{\text {hitung }}$, maka dapat disimpulkan karena harga $r \neq 0$ maka $H_{a}$ diterima dan $H_{0}$ ditolak dengan koefisien korelasi $r_{\text {hitung }}=0,907$ dengan $\mathrm{N}=25$ dan taraf kesalahan $1 \%$ diperoleh $r_{\text {tabel }}=0,505$ dapat disimpulkan $r_{\text {hitung }}>$ $r_{\text {tabel }}$ ada hubungan antara sikap siswa pada matematika terhadap hasil belajar dengan tingkat interpretasi sangat kuat.

c. Analisis Regresi Linear Sederhana

Menghitung persamaan umum analisis regresi linear sederhana dengan menggunakan program SPSS, ditunjukkan dalam Tabel 3.

Coefficients $^{\mathrm{a}}$

Tabel 3. Analisis Regresi Linear Sederhana

\begin{tabular}{|c|c|c|c|c|c|}
\hline \multirow[b]{2}{*}{ Model } & \multicolumn{2}{|c|}{$\begin{array}{l}\text { Unstandardized } \\
\text { Coefficients }\end{array}$} & $\begin{array}{l}\text { Standardized } \\
\text { Coefficients }\end{array}$ & \multirow[b]{2}{*}{$\mathrm{t}$} & \multirow[b]{2}{*}{ Sig. } \\
\hline & B & Std. Error & Beta & & \\
\hline (Constant) & 19.761 & 4.617 & & 4.280 & .000 \\
\hline Sikap Siswa Pada Matematika & .989 & .096 & .907 & 10.355 & .000 \\
\hline
\end{tabular}

a. Dependent Variable: Hasil Belajar

Dari Hasil perhitungan dengan menggunakan program SPSS dapat ditentukan nilai a $=19,761$ dan nilai $b=0,989$ dengan demikian hasil yang diperoleh, yaitu koefisien arah regresi sebesar 0,989 dan persamaan regresinya adalah $\hat{Y}=19,8+0,99 x$. Selanjutnya akan menghitung uji $\mathrm{F}$ dengan menggunakan uji Analisis Varians Ganda (ANAVA) pada program SPSS, ditunjukkan dalam Tabel 4.

ANOVA $^{\mathrm{b}}$

Tabel 4. Uji Analisis Varians Ganda

\begin{tabular}{|c|c|c|c|c|c|}
\hline Model & Sum of Squares & Df & Mean Square & $\mathrm{F}$ & Sig. \\
\hline Regression & 1819.663 & 1 & 1819.663 & 107.221 & $.000^{\mathrm{a}}$ \\
\hline Residual & 390.337 & 23 & 16.971 & & \\
\hline Total & 2210.000 & 24 & & & \\
\hline
\end{tabular}

a. Predictors: (Constant), Sikap Siswa Pada Matematika

b. Dependent Variable: Hasil Belajar

Menurut Gunawan (2015:191) Jika $F_{\text {hitung }}>F_{\text {tabel }}$ pada nilai signifikan $\alpha(0,05)$, maka $F_{\text {hitung }}$ pada koefisien regresi adalah berarti (bermakna). Dari tabel tersebut hasil perhitungan $F_{\text {hitung }}=107,221$ dengan $F_{\text {tabel }}=4,28$ dapat disimpulkan $F_{\text {hitung }}$ lebih besar dari pada $F_{\text {tabel }}$ yaitu 107,221 > 4,28 sehingga $H_{0}$ ditolak dan 
$H_{a}$ diterima. Dari hasil perhitungan tersebut menunjukkan sikap siswa pada matematika memiliki pengaruh yang bermakna terhadap hasil belajar, sehingga $H_{0}$ ditolak dan $H_{a}$ diterima. Artinya terdapat pengaruh antara sikap siswa pada matematika terhadap hasil belajar.

d. Koefisien Determinasi

Koefisien determinasi digunakan untuk mengetahui seberapa besar persentase pengaruh variabel independen terhadap variabel dependen, maka perlu menguji besarnya koefisien determinasi $(K d)$ dengan menggunakan program SPSS yang ditunjukkan dalam Tabel 5.

Tabel 5. Koefisien Determinasi

Model Summary

\begin{tabular}{|l|r|r|r|r|}
\hline Model & \multicolumn{1}{|c|}{ R } & R Square & Adjusted R Square & Std. Error of the Estimate \\
\hline 1 & $.907^{\mathrm{a}}$ & .823 & .816 & 4.11961 \\
\hline
\end{tabular}

a. Predictors: (Constant), Sikap Siswa Pada Matematika

Hasil dari perhitungan koefisien determinasi adalah 82,3\%, sehingga dapat diketahui bahwa sikap siswa pada matematika berpengaruh terhadap hasil belajar.

\section{SIMPULAN DAN SARAN}

Hasil penelitian ini menunjukkan bahwa terdapat hubungan antara sikap siswa pada matematika terhadap hasil belajar dengan koefisien korelasi $r_{\text {hitung }}=0,907$ dengan $\mathrm{N}=25$ dan taraf kesalahan $1 \%$ diperoleh $r_{\text {tabel }}=0,505$ dapat disimpulkan $r_{\text {hitung }}>r_{\text {tabel }}$ ada hubungan antara sikap siswa pada matematika terhadap hasil belajar dengan tingkat interpretasi sangat kuat. Hasil perhitungan persamaan umum analisis regresi linear sederhana $\hat{Y}=19,8+0,99 x$ dengan koefisien determinasi sebesar 82,3\% dan hasil perhitungan $F_{\text {hitung }}=107,221$ dengan $F_{\text {tabel }}=4,28$ dapat disimpulkan $F_{\text {hitung }}$ lebih besar dari pada $F_{\text {tabel }}$ yaitu $107,221>4,28$ sehingga $H_{0}$ ditolak dan $H_{a}$ diterima.

Dari hasil perhitungan tersebut dapat disimpulkan bahwa sikap siswa pada matematika memiliki pengaruh terhadap hasil belajar, sehingga $H_{0}$ ditolak dan $H_{a}$ diterima. Artinya terdapat pengaruh antara sikap siswa pada matematika terhadap hasil belajar sebesar $82,3 \%$. Hasil belajar matematika dipengaruhi sebesar 82,3\% oleh sikap siswa pada matematika, sisanya $17,7 \%$ dipengaruhi oleh faktor lain. 


\section{DAFTAR PUSTAKA}

Gunawan, M. (2015). Statistik Penelitian Bidang Pendidikan, Psikologi Dan Sosial. Yogyakarta : Parama Publishing.

Sudjana, N. (2011). Penelitian Hasil Proses Belajar Mengajar. Bandung : Remaja Rosdakarya.

Sugiyono. (2013). Metode Penelitian Kuantitatif Kualitatif dan R\&D. Bandung : Alfabeta.

Sukardi. (2003). Metedologi Penelitian Pendidikan. Jakarta: Bumi Aksara.

Syah, M. (2003). Psikologi Belajar. Jakarta: PT. Raja Grafindo Persada.

Yusuf, dkk. (2005). Landasan Bimbingan dan Konseling. Bandung : Remaja Rosdakarya. 